\title{
Trans fatty acids and coronary artery disease
}

This article was published in the following Dove Press journal:

Open Access Journal of Clinical Trials

16 January 2010

Number of times this article has been viewed

\section{Jocelyne R Benatar}

Green Lane Cardiovascular Service, Auckland City Hospital, Auckland, New Zealand
Correspondence: Jocelyne Benatar Cardiovascular Research Unit, Green Lane Cardiovascular Service, Auckland City Hospital, Auckland 1030, New Zealand Tel +6493074949

Fax +6496309978

Email jbenatar@adhb.govt.nz
Abstract: There has been a significant increased consumption of trans fats in the developed world as we have embraced processed and take away foods in our diet in the last 40 years. These fatty acids are not essential for human nutrition and are hazardous to health. They increase the risk of cardiovascular disease more than any other macronutrient including saturated fat, through multiple mechanisms including adverse effects on lipids, endothelial function and inflammation. They are readily incorporated into cell structures such as cell membranes and the Golgi apparatus, resulting in unintended effects on multiple biological pathways. The majority of trans fats in our diet are artificially manufactured by a process of partial hydrogenation of vegetable oil with little coming from natural sources. It should be possible to replace these harmful fats in the food chain at source with concerted efforts from food manufacturers and legislators.

Keywords: trans fats, coronary artery disease, hydrogenated vegetable oils

\section{Introduction}

Approximately a century ago the discovery was made that liquid vegetable oil could be converted by a process of hydrogenation to a useful solid fat. The process for making hydrogenated and hardened fats from cheaper sources of vegetable oils was widely adopted after the Second World War and the consumption of these fats soared in the 1970s. ${ }^{1}$

An unintended effect of the process was the creation of a by-product called trans fatty acids (TFA). TFA are not essential for human nutrition and have subsequently been found to be hazardous to health with adverse effects on cardiovascular disease, prostate cancer and female infertility.

This article reviews the evidence linking cardiovascular disease and TFA intake.

\section{What are trans fats}

Fatty acids are water-insoluble molecules with long carbon chains (Figure 1) that have a wide variety of functions within cells including:1) maintenance of electrochemical gradients across membranes; 2) first and second messenger signalling; 3) energy storage; 4) sub cellular partitioning and; 5) protein trafficking and membrane anchoring. ${ }^{2}$

The terms saturated, polyunsaturated, and unsaturated relate to the presence or absence of double bonds between the carbon atoms. Saturated fats have no double bonds between carbon atoms whereas unsaturated fats have double bonds between carbon molecules. Fatty acids with a single double bond are monounsaturated and those with multiple double bonds are polyunsaturated. ${ }^{3}$ submit your manuscript | www.dovepress.com

Dovepress 


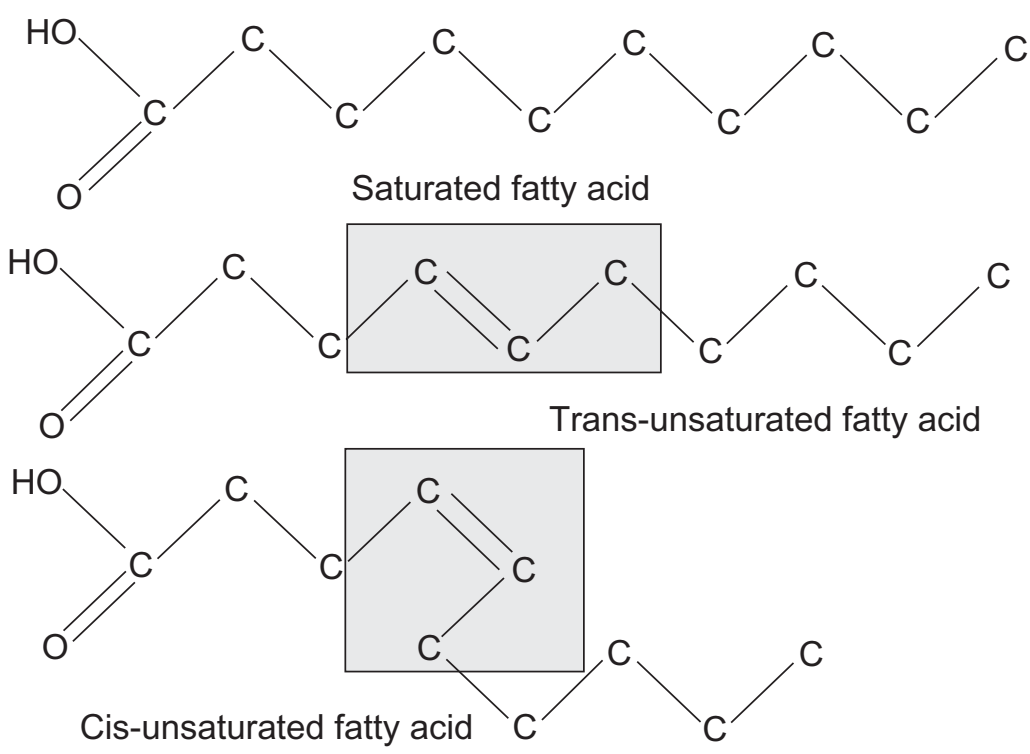

Figure I Schematic of saturated fatty acid, trans fatty acid, and unsaturated fatty acid.

The double bond mainly exists in the cis configuration, and when that double bond is 'flipped over', it exists in the trans configuration. The trans configuration inherently changes the properties of the fatty acid including the ability of the molecule to 'bend'. The type of fatty acid incorporated into cell structures has the potential to affect multiple cellular functions including cell membrane receptor activity.

\section{Source of TFA}

Humans do not produce TFA and all comes from the diet. Two sources of TFA are found; in products derived from ruminant animals, such as milk and meat, and in foods that contain artificially manufactured hydrogenated vegetable oil. Both are derived from hydrogenation of unsaturated fats. In the case of ruminant TFA, the bacteria in the ruminant animal's gut hydrogenate the fatty acids.

The amount of TFA and the kind of TFA produced in milk and meat is determined by what the animal eats ${ }^{4}$ with cows that graze producing more TFA than those that are grain fed. The predominant isomer of TFA found in milk is vaccenic acid (Trans $18: 1 \mathrm{n} 7$ ). It makes up 55\% of total trans $18: 1$ isomers in milk fat from grazing cows compared with 33\% in milk from cows fed a grain diet. In most Western countries, only trace amounts TFA ingested is from dairy sources and studies to date have not convincingly shown that ruminant trans fats are harmful. ${ }^{5,6}$

In contrast, there is considerable data suggesting hydrogenated vegetable oils are harmful. ${ }^{7-11}$ Hydrogenated oils are solid at room temperature, have a high smoke point and a long shelf life. This allows for an unsaturated fat as an alternative spread to butter, which is an attractive option to consumers worried about saturated fat intake. It enables fast food outlets to fry foods at high temperatures and manufacturers to produce goods, such as biscuits and snacks, with a long shelf life. Industrially processed foods have been embraced in the Western world and account for the majority of TFA intake in Western countries. The most common isomers of TFA found in industrially processed food is elaidic acid (trans 18:1n9).

\section{Human intake of TFA}

Humans ingest several isomers of TFA and the common ones are listed in Table 1. In most countries, TFA derive predominantly from hydrogenated vegetable oils, but in some countries like Denmark and New Zealand, there is little intake of processed food and a high intake of dairy TFA.

Table I Common TFA isomers ingested by humans

\begin{tabular}{llll}
\hline $\begin{array}{l}\text { Shorthand } \\
\text { designation }\end{array}$ & $\begin{array}{l}\text { Common } \\
\text { name }\end{array}$ & $\begin{array}{l}\text { Systematic } \\
\text { name }\end{array}$ & Source \\
\hline Trans I8 In7 & Vaccenic acid & $\begin{array}{l}\text { Trans-II- } \\
\text { octadecenoic } \\
\text { acid }\end{array}$ & Ruminant \\
Trans 18 In9 & Elaidic acid & $\begin{array}{l}\text { Trans-9- } \\
\text { octadecenoic } \\
\text { acid }\end{array}$ & Industrial \\
Trans 18:2 & Linoelaidic acid & $\begin{array}{l}\text { Trans-9, trans- } \\
\text { I2-linoleic acid }\end{array}$ & Industrial \\
Trans 16:1 & Palmitelaidic acid & $\begin{array}{l}\text { 9-trans- } \\
\text { hexadecenoic acid }\end{array}$ & $\begin{array}{l}\text { Ruminant, palm } \\
\text { oil derivative }\end{array}$ \\
\hline
\end{tabular}

Abbreviation: TFA, trans fatty acids. 
Dietary surveys show that there has been a large increase in industrial TFA consumption from the 1970s onwards and that the average consumption in north America nowadays is $2 \%-3 \%$ of total calories consumed with less than $0.5 \%$ derived from ruminant sources. ${ }^{1}$

\section{Biological effects of TFA}

Studies have shown that TFA have adverse effects on lipids, ${ }^{12-20}$ inflammation, ${ }^{21-24}$ cell wall fluidity, and endothelial function (Figure 2). ${ }^{25-27}$

Metabolic and meta-analysis show a clear and consistent association between increased TFA intake and reduced high-density lipoprotein-cholesterol (HDL-C), increased low-density lipoprotein-cholesterol (LDL-C) and triglyceride levels. These studies have also shown that TFA increase lipoprotein(a) and reduce the particle size of LDL-C, both of which contribute to an increased risk of cardiovascular disease (CVD). Changes in lipids caused by TFA do not completely account for the increased risk of CVD seen in epidemiological studies. Residual risk is due to effects on inflammation and endothelial function.

Effects on inflammation are seen in both epidemiological and experimental studies. A study of over 700 nurses showed that those in the highest quartile of trans fat consumption had blood levels of CRP that were $73 \%$ higher than those in the lowest quartile. ${ }^{26}$ Other studies have also linked significant intake of TFA with increased circulating concentrations of inflammatory molecules such as interleukin-6, tumor necrosis factor-alpha, C-reactive protein, and monocyte chemoattractant protein-1.

Several studies suggest that TFA cause endothelial dysfunction. After adjustment for other risk factors, greater intake of trans fatty acids was associated with increased levels of several markers of endothelial dysfunction, including soluble intercellular adhesion molecule 1, soluble vascularcell adhesion molecule 1, and E-selectin. ${ }^{9,28}$ In another trial, consumption of trans fatty acids impaired endothelial function, as reflected by a reduction in brachial artery flowmediated vasodilatation by $29 \%$, as compared with intake of saturated fat. ${ }^{22}$

\section{Cardiovascular disease and trans fat intake}

Studies have shown a graded association between increased dietary intake of TFA, predominantly hydrogenated vegetable oil and the risk of CVD. In a meta-analysis of three prospective cohort studies which included $\sim 140,000$ subjects, an increase in $2 \%$ of energy from TFAs (or a teaspoonful a day) estimated from detailed food-frequency questionnaires was associated with a $\sim 25 \%$ increase in the risk of CVD. ${ }^{9}$

The major evidence for the effect of TFA on coronary heart disease (CHD) comes from the Nurses' Health Study (NHS); a cohort study that has been following 120,000 female nurses since its inception in 1976. In this study, data from 900 coronary events from the NHS population during 14 years of follow up was analyzed. CHD risk almost doubled

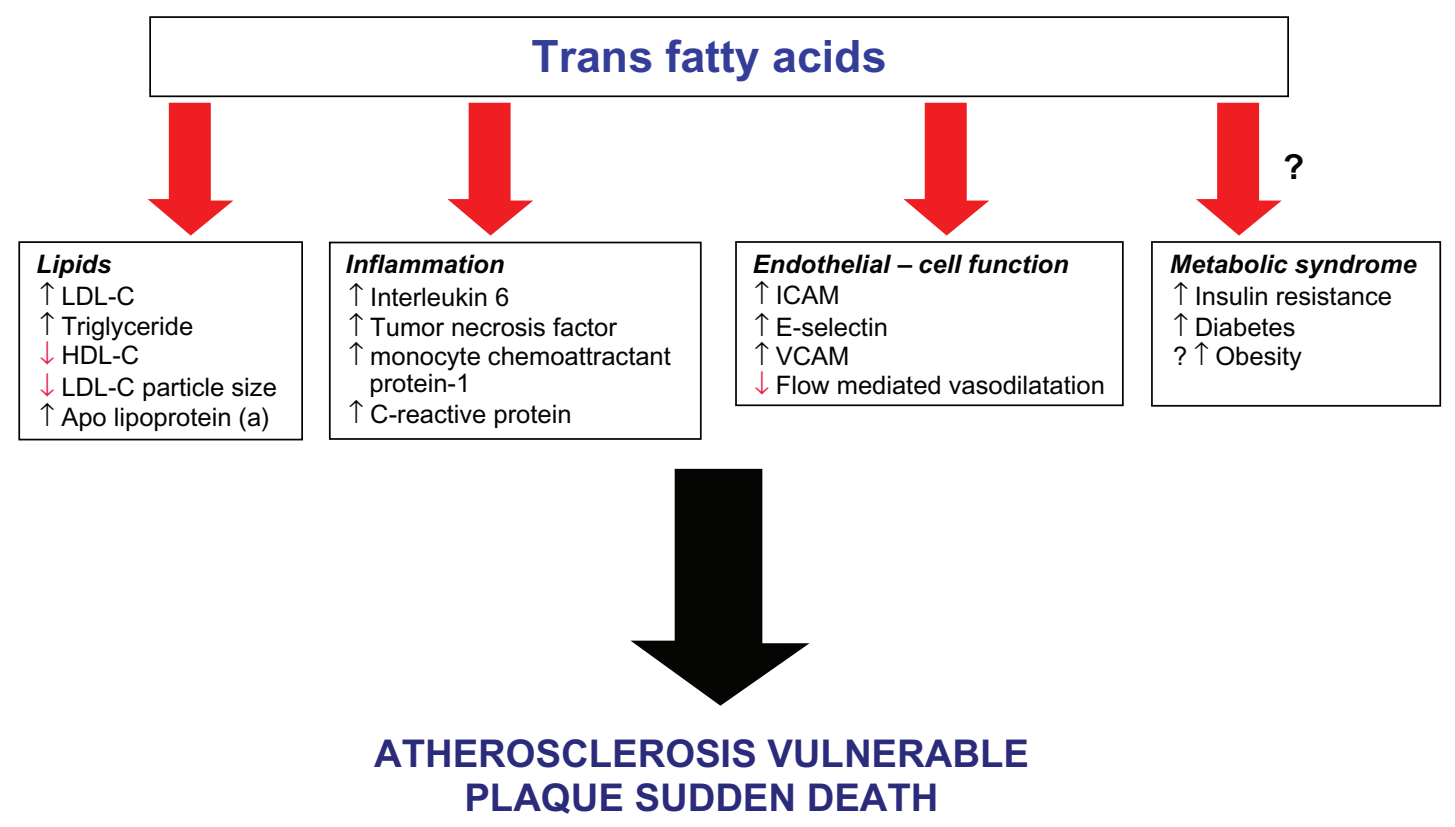

Figure 2 Multiple pathways by which trans fatty acids cause cardiovascular disease.

Abbreviations: HDL-C, high-density lipoprotein-cholesterol; ICAM, intercellular adhesion molecule; LDL-L, low-density lipoprotein-cholesterol; VCAM, vascular cell adhesion molecule. 
for each $2 \%$ increase in TFA calories consumed. To put this in context, saturated fat needs to be $15 \%$ of total calories to achieve the same level of risk. ${ }^{29,30}$

Studies testing TFA tissue levels in serum, adipose tissue, and erythrocytes have shown a strong positive correlation between CVD risk and tissue concentration of TFA., ${ }^{70,11,30-32}$ Two studies have linked the risk of sudden death from cardiac causes and levels of TFA, specifically the industrial TFA trans18:2 (linoelaidic acid).

Studies are not consistent about whether specific TFA isomers have different effects on CHD risk. Elaidic acid has been associated with increased risk of sudden death, fatal ischemic heart disease and acute coronary syndrome. ${ }^{7,10,11,30-32}$

The data on effects of ruminant TFA is less convincing ${ }^{6}$ with studies showing either neutral or adverse effects. The lack of biological effect of ruminant fats in these studies may in part be due to low levels of intake (typically less than $0.5 \%$ of total energy intake) in most Western countries.

\section{Trans fats, the metabolic syndrome, and diabetes}

There is no consistent data as to whether TFA increase the risk of the metabolic syndrome or diabetes..$^{33-39}$ The association between TFA intake and obesity disappears when corrected for caloric intake .The Nurses Health Study showed that the intake of TFA was significantly related to the risk of diabetes in 84,941 nurses. ${ }^{34}$ This was not validated in two other studies, the Physician Health Study and a study in the women of Iowa. Possible reasons for the disparity is that the nurses had a significantly higher intake of TFA compared to their physician counterparts and the Iowa study was flawed in that diabetes was based on self-reports and diet was assessed only at baseline.

\section{Reducing the exposure to TFA}

The elimination of industrially manufactured nonessential TFA should be achievable. ${ }^{28}$ This laudable goal needs to be reached without inadvertently replacing TFA with saturated fats. There is also growing concern that emphasizing the danger of TFA consumption may shift the focus away from the dangers of saturated fat consumption and add to the complexity consumers face when reading food labels.

The WHO recommends that TFA intake be less than $1 \%$ of total caloric intake with most advice tailored towards reducing industrial TFA. ${ }^{40}$ The Food and Drug Administration has recommended that all TFA be on the nutrition label. Food labelling may give consumers choice, but requires extensive education programs. It is more pragmatic to eliminate TFA at source and reduce levels in the food chain.
Healthier alternative oils with high smoke points such as rice bran oils are now available for deep fat fryers and changed formulations have allowed elimination of TFA from margarines. Food manufacturers are investigating hydrogenation of fatty acids without producing the harmful TFA byproduct. In countries with high ruminant TFA intake, a number of methods can be considered to reduce TFA levels including manipulating the animal's diet and filtration of the milk.

A number of countries, such as Denmark and Switzerland, have effectively legislated to eliminate industrial TFAs. Others, such as the US and Britain have implemented voluntary measures to reduce TFA in food.

\section{Conclusion}

Our consumer culture has produced many environmental hazards in the name of progress and convenience. Processed food consumption is linked with a number of heath hazards, some attributable to the presence of TFA.

TFA are nonessential fatty acids, with no benefit for human health, conversely; most studies have shown that TFA consumption is hazardous to health specifically cardiovascular health. Whilst it may be impossible to eliminate TFA from the food chain, steps to minimize exposure to hydrogenated vegetable oils is achievable with concerted efforts from legislators, manufacturers and consumers. The experience from countries like Denmark indicates that this is an achievable goal.

\section{Disclosure}

The author reports no conflicts of interest in this work.

\section{References}

1. Food and Nutrition Board. Dietary Reference Intakes for Energy, Carbohydrate, Fiber, Fat, Fatty Acids, Cholesterol, Protein, and Amino Acids (Macronutrients). Washington, DC: National Academies Press, 2005.

2. Watson AD. Thematic review series: systems biology approaches to metabolic and cardiovascular disorders. Lipidomics: a global approach to lipid analysis in biological systems. J Lipid Res. 2006;47(10): 2101-2111.

3. Christie WW. Fatty acids: Straight-chain monoenoic, structures, occurrence and biochemistry. October 5, 2009. Available from: http://www. lipidlibrary.co.uk/Lipids/fa_mono/index.htm. Accessed October 27, 2009.

4. Loor JJ, Herbein JH, Polan CE. Trans18:1 and 18:2 isomers in blood plasma and milk fat of grazing cows fed a grain supplement containing solvent-extracted or mechanically extracted soybean meal. J Dairy Sci. 2002;85(5):1197-1207.

5. Sun Q, Ma J, Campos H, Hu FB. Plasma and erythrocyte biomarkers of dairy fat intake and risk of ischemic heart disease. Am J Clin Nutr. 2007;86(4):929-937.

6. Jakobsen MU, Bysted A, Andersen NL, et al. Intake of ruminant trans fatty acids and risk of coronary heart disease-an overview. Atheroscler Suppl. 2006;7(2):9-11. 
7. Oomen CM, Ocke MC, Feskens EJ, Erp-Baart MA, Kok FJ, Kromhout D. Association between trans fatty acid intake and 10 -year risk of coronary heart disease in the Zutphen Elderly Study: a prospective populationbased study. Lancet. 2001;357(9258):746-751.

8. Willett WC, Stampfer MJ, Manson JE, et al. Intake of trans fatty acids and risk of coronary heart disease among women. Lancet. 1993;341(8845):581-585.

9. Mozaffarian D, Katan MB, Ascherio A, Stampfer MJ, Willett WC. Trans fatty acids and cardiovascular disease. $N$ Engl J Med. 2006; 354(15):1601-1613.

10. Sun Q, Ma J, Campos H, et al. A prospective study of trans fatty acids in erythrocytes and risk of coronary heart disease. Circulation. 2007;115(14): 1858-1865.

11. Lemaitre RN, King IB, Mozaffarian D, et al. Plasma phospholipid trans fatty acids, fatal ischemic heart disease, and sudden cardiac death in older adults: the cardiovascular health study. Circulation. 2006;114(3):209-215.

12. Mensink RP, Katan MB. Effect of dietary trans fatty acids on highdensity and low-density lipoprotein cholesterol levels in healthy subjects. N Engl J Med. 1990;323(7):439-445.

13. Mensink RP, Zock PL, Kester AD, Katan MB. Effects of dietary fatty acids and carbohydrates on the ratio of serum total to HDL cholesterol and on serum lipids and apolipoproteins: a meta-analysis of 60 controlled trials. Am J Clin Nutr. 2003;77(5):1146-1155.

14. Mensink RP, Zock PL, Katan MB, Hornstra G. Effect of dietary cis and trans fatty acids on serum lipoprotein[a] levels in humans. J Lipid Res. 1992;33(10):1493-1501.

15. Zock PL, Katan MB. Hydrogenation alternatives: effects of trans fatty acids and stearic acid versus linoleic acid on serum lipids and lipoproteins in humans. J Lipid Res. 1992;33(3):399-410.

16. Judd JT, Clevidence BA, Muesing RA, Wittes J, Sunkin ME, Podczasy JJ. Dietary trans fatty acids: effects on plasma lipids and lipoproteins of healthy men and women. Am J Clin Nutr. 1994;59(4):861-868.

17. Almendingen K, Jordal O, Kierulf P, Sandstad B, Pedersen JI. Effects of partially hydrogenated fish oil, partially hydrogenated soybean oil, and butter on serum lipoproteins and $\mathrm{Lp}[\mathrm{a}]$ in men. J Lipid Res. 1995;36(6):1370-1384.

18. Aro A, Jauhiainen M, Partanen R, Salminen I, Mutanen M. Stearic acid, trans fatty acids, and dairy fat: effects on serum and lipoprotein lipids, apolipoproteins, lipoprotein(a), and lipid transfer proteins in healthy subjects. Am J Clin Nutr. 1997;65(5):1419-1426.

19. Judd JT, Baer DJ, Clevidence BA, et al. Effects of margarine compared with those of butter on blood lipid profiles related to cardiovascular disease risk factors in normolipemic adults fed controlled diets. Am J Clin Nutr. 1998;68(4):768-777.

20. Mauger JF, Lichtenstein AH, Ausman LM, et al. Effect of different forms of dietary hydrogenated fats on LDL particle size. Am J Clin Nutr. 2003;78(3):370-375.

21. Mozaffarian D, Pischon T, Hankinson SE, et al. Dietary intake of trans fatty acids and systemic inflammation in women. Am J Clin Nutr. 2004;79(4):606-612.

22. Baer DJ, Judd JT, Clevidence BA, Tracy RP. Dietary fatty acids affect plasma markers of inflammation in healthy men fed controlled diets: a randomized crossover study. Am J Clin Nutr. 2004;79(6):969-973.

23. Mozaffarian D, Rimm EB, King IB, Lawler RL, McDonald GB, Levy WC. Trans fatty acids and systemic inflammation in heart failure. $\mathrm{Am}$ J Clin Nutr. 2004;80(6):1521-1525.
24. Han SN, Leka LS, Lichtenstein AH, Ausman LM, Schaefer EJ, Meydani SN. Effect of hydrogenated and saturated, relative to polyunsaturated, fat on immune and inflammatory responses of adults with moderate hypercholesterolemia. J Lipid Res. 2002;43(3):445-452.

25. Harvey KA, Arnold T, Rasool T, Antalis C, Miller SJ, Siddiqui RA. Trans-fatty acids induce pro-inflammatory responses and endothelial cell dysfunction. Br J Nutr. 2008;99(4):723-731.

26. Lopez-Garcia E, Schulze MB, Meigs JB, et al. Consumption of trans fatty acids is related to plasma biomarkers of inflammation and endothelial dysfunction. J Nutr. 2005;135(3):562-566.

27. de Roos NM, Bots ML, Katan MB. Replacement of dietary saturated fatty acids by trans fatty acids lowers serum HDL cholesterol and impairs endothelial function in healthy men and women. Arterioscler Thromb Vasc Biol. 2001;21(7):1233-1237.

28. Katan MB. Regulation of trans fats: the gap, the Polder, and McDonald's French fries. Atheroscler Suppl. 2006;7(2):63-66.

29. Oh K, Hu FB, Manson JE, Stampfer MJ, Willett WC. Dietary fat intake and risk of coronary heart disease in women: 20 years of follow-up of the nurses' health study. Am J Epidemiol. 2005;161(7):672-679.

30. Hu FB, Stampfer MJ, Manson JE, et al. Dietary fat intake and the risk of coronary heart disease in women. $N$ Engl J Med. 1997;337(21): 1491-1499.

31. Lemaitre RN, King IB, Raghunathan TE, et al. Cell membrane trans-fatty acids and the risk of primary cardiac arrest. Circulation. 2002;105(6):697-701.

32. Harris WS, Reid KJ, Sands SA, Spertus JA. Blood omega-3 and trans fatty acids in middle-aged acute coronary syndrome patients. Am J Cardiol. 2007;99(2):154-158.

33. Saravanan N, Haseeb A, Ehtesham NZ, Ghafoorunissa. Differential effects of dietary saturated and trans-fatty acids on expression of genes associated with insulin sensitivity in rat adipose tissue. Eur $J$ Endocrinol. 2005;153(1):159-165.

34. Salmeron J, Hu FB, Manson JE, et al. Dietary fat intake and risk of type 2 diabetes in women. Am J Clin Nutr. 2001;73(6):1019-1026.

35. Vessby B, Unsitupa M, Hermansen K, et al. Substituting dietary saturated for monounsaturated fat impairs insulin sensitivity in healthy men and women: The KANWU Study. Diabetologia. 2001;44(3): 312-319.

36. Louheranta AM, Turpeinen AK, Vidgren HM, Schwab US, Uusitupa MI. A high-trans fatty acid diet and insulin sensitivity in young healthy women. Metabolism. 1999;48(7):870-875.

37. Lovejoy JC, Smith SR, Champagne CM, et al. Effects of diets enriched in saturated (palmitic), monounsaturated (oleic), or trans (elaidic) fatty acids on insulin sensitivity and substrate oxidation in healthy adults. Diabetes Care. 2002;25(8):1283-1288.

38. Lichtenstein AH, Erkkila AT, Lamarche B, Schwab US, Jalbert SM, Ausman LM. Influence of hydrogenated fat and butter on CVD risk factors: remnant-like particles, glucose and insulin, blood pressure and C-reactive protein. Atherosclerosis. 2003;171(1):97-107.

39. Christiansen E, Schnider S, Palmvig B, Tauber-Lassen E, Pedersen O. Intake of a diet high in trans monounsaturated fatty acids or saturated fatty acids. Effects on postprandial insulinemia and glycemia in obese patients with NIDDM. Diabetes Care. 1997;20(5):881-887.

40. World Health Organisation. WHO Scientific Update on Trans Fatty Acids (TFA). 2009. Available from: http://www.who.int/nutrition/topics/ trans_fatty_acids. Accessed October 27, 2009.

\section{Dovepress}

\section{Publish your work in this journal}

The Open Access Journal of Clinical Trials is an international, peerreviewed, open access journal publishing original research, reports, editorials, reviews and commentaries on all aspects of clinical tria design, management, legal, ethical and regulatory issues, case record form design, data collection, quality assurance and data auditing

methodologies. The manuscript management system is completely online and includes a very quick and fair peer-review system, which is all easy to use. Visit http://www.dovepress.com/testimonials.php to read real quotes from published authors. 